\title{
CLINICAL AND EPIDEMIOLOGICAL FEATURES OF THE NEW CORONAVIRUS INFECTION COVID-19 IN THE CENTRAL BLACK REGION
}

Esaulenko IE $₫$, Popov VI, Petrova TN, Goncharov AYu

Voronezh State Medical University, Voronezh

The article provides an analysis of a large-scale epidemic outbreak caused by human coronaviruses. The epidemiological situation in the world and the Russian Federation is analyzed, which forced specialists to significantly increase the level of epidemiological danger from coronaviruses. The epidemic situations of the incidence in six regions of the Central Black Earth Region are described, the dynamics and regional features of the spread and nature of the course of the new coronavirus infection Covid-19 are generalized and systematized. Some epidemiological aspects of this infection in the territory of the Voronezh region are described. The dynamics of the epidemic process is described and a number of epidemiological indicators are analyzed (daily increase in morbidity and mortality, distribution of the duration of lethal diseases, risk groups, etc.). The clinical and epidemiological features of the combined forms of infections are analyzed: the prevalence of a moderate course, the risk of complications in risk groups. The difficulty of verifying this infection from other viral infections based on the clinical picture, the high virulence and severity of the course has been established. It was shown that the mobilization of health care to combat coronavirus infection revealed the main thing: the health care system has resources and mechanisms through which it is possible to quickly switch to work in extreme conditions. New hospitals and beds, re-equipment with diagnostic and resuscitation equipment, accelerated retraining of doctors. All this was effective evidence that an adequate potential supply of resources will not only reduce the consequences of possible epidemics in the future, but also during the period outside the epidemic will help accelerate the adoption of effective decisions and improve the quality of medical care for the population.

Keywords: coronavirus; coronavirus infection; pneumonia; treatment; safety in extreme situations

$\triangle$ Correspondence should be addressed: Petrova TN

stud.forum@mail.ru, +7(920) 4042306

Received: 14.07.2020 Accepted: 17.07.2020 Published online: 26.07.2020

DOI: 10.47183/mes.2020.001

\section{КЛИНИКО-ЭПИДЕМИОЛОГИЧЕСКИЕ ОСОБЕННОСТИ НОВОЙ КОРОНАВИРУСНОЙ ИНФЕКЦИИ COVID-19 В ЦЕНТРАЛЬНО-ЧЕРНОЗЕМНОМ РЕГИОНЕ РОССИИ}

\author{
И. Э. Есауленко $\bowtie$, В. И. Попов, Т. Н. Петрова, А. Ю. Гончаров
}

Воронежский государственный медицинский университет имени Н. Н. Бурденко, Воронеж

\begin{abstract}
В статье приведен анализ масштабной эпидемической вспышки, обусловленой коронавирусами, патогенными для человека. Проанализирована эпидемиологическая ситуация в мире и Российской Федерации, которая заставила специалистов существенно повысить уровень эпидемиологической опасности со стороны коронавирусов. Описаны эпидемические ситуации по заболеваемости в шести областях Центрально-Черноземного региона, обобщены и систематизированы динамика и региональные особенности распространения и характера течения новой коронавирусной инфекции Covid-19. Описаны некоторые эпидемиологические аспекты данной инфекции на территории Воронежской области. Описывается динамика эпидемического процесса и анализируется ряд эпидемиологических показателей (ежедневный прирост заболеваемости и смертности, распределение продолжительности летальных заболеваний, группы риска и т.д.). Проанализированы клинико-эпидемиологические особенности сочетанных форм инфекций: преобладание среднетяжелого течения, риск развития осложнений в группах риска. Установлена сложность верификации данной инфекции от других вирусных инфекций на основе клинической картины, высокая вирулентность и тяжесть течения. Показано, что проведенная мобилизация здравоохранения для борьбы с коронавирусной инфекцией выявила главное: у системы здравоохранения есть ресурсы и механизмы, благодаря которым можно быстро перестроиться на работу в экстремальных условиях. Новые госпитали и койки, дооснащение диагностическим и реанимационным оборудованием, ускоренное переобучение медиков. Все это являлось действенным доказательством того, что адекватный потенциальный запас ресурсов не только позволит уменьшить последствия от возможных эпидемий в будущем, но и в период вне эпидемии поможет ускорить принятие эффективных решений и улучшить качество медицинской помощи населению.
\end{abstract}

Ключевые слова: коронавирус, коронавирусная инфекция, пневмония, лечение, безопасность в экстремальных ситуациях

$\checkmark$ Для корреспонденции: Петрова Татьяна Николаевна - доктор медицинских наук, профессор, проректор по развитию регионального здравоохранения ФГБОУ ВО ВГМУ им.Н.Н. Бурденко МЗ РФ, e-mail stud.forum@mail.ru +7(920) 4042306

Статья получена: 14.07.2020 Статья принята к печати: 17.07.2020 Опубликована онлайн: 26.07.2020

DOI: $10.47183 /$ mes.2020.001

Throughout its history, mankind has seen countless epidemics and pandemics take millions of lives. In the new millennium, typhoid fever and plague have become a thing of the past. But climate change and other environmental factors have given rise to novel viruses whose swift spread across the globe is driven by high population density and migration [6].

In late 2019, the World Health Organization declared an outbreak of a novel coronavirus disease (COVID-19). According to John Hopkins University, USA, there were over 11 million confirmed COVID-19 cases worldwide in early July 2020 [2]. Currently, the United States ranks first in the total number of infections (2.8 million) [3, 4], followed by Brazil (1.5 million) and Russia (670, 000). In Russia, there has been 10,027 confirmed deaths so far, with the case fatality rate being $1.49 \%[5,6]$.

By March 2020, the pandemic had reached the Black Earth Belt of central Russia, where the first COVID-19 cases were reported in Lipetsk region. The infection soon spread to 5 other regions of the Russian Black Earth Belt, including Voronezh, Kursk, Oryol, Tambov, and Belgorod [7, 8].

The aim of this study was to systematize data on COVID-19 collected in the Black Earth Belt region of Central Russia. 


\section{METHODS}

The study was conducted using the established methodology for epidemiological surveillance which relies on analytical, descriptive, evaluative, and statistical techniques, mathematical modeling and prediction.

For the purpose of this study, we developed a framework based on the conceptual premises of basic and applied research in virology and highly infectious diseases proposed by Russian and foreign authors.

\section{RESULTS AND DISCUSSION}

We have analyzed data collected in 6 regions of the Black Earth Belt in central Russia. This analysis allowed us to identify both countrywide and regional patterns of COVID-19 spread (Fig.1).

The first cases of the novel coronavirus infection in Voronezh region were reported in March 2020. By July 2020, the total number of cases had gone beyond 8, 000 (Fig. 2), growing by $22.1 \%$ in comparison with March (Fig.3).
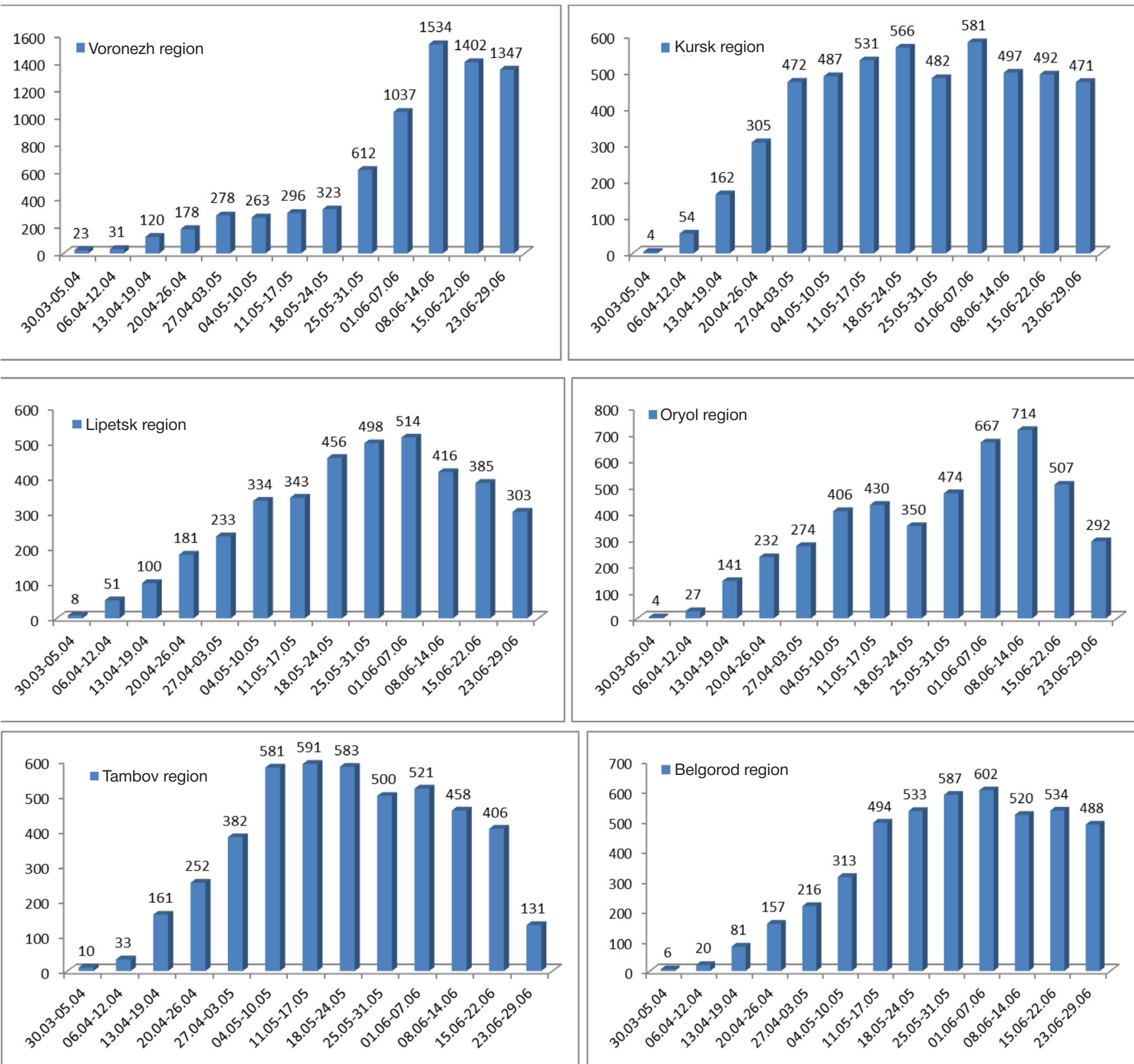

In June, the number of new cases peaked, reaching 3,351 (Fig.4).

From June, 15 to June, 21 there were over 200 confirmed daily cases in Voronezh region. By complying with stringent containment measures imposed by the government, the region was able to bring the spread of the disease under control. Since the end of June, there has been a downward trend in daily cases. In the last few days, the number of daily cases was just slightly over 100 (Fig. 5).

However, the risk of coronavirus spread in Voronezh region is still high. The average reproductive number is 4 . Despite an insignificant decline in daily cases, the total number of confirmed infections continues to grow (Fig.6).

Having analyzed the medical histories and autopsy reports for suspected COVID-19 cases, the task force working group for Voronezh region concluded that the novel coronavirus infection affects the course of some chronic conditions and can cause exacerbations. Traces of the virus were detected in patients' nasal and pharyngeal specimens, kidneys, liver, pancreas, myocardium, tears, and feces. According to the

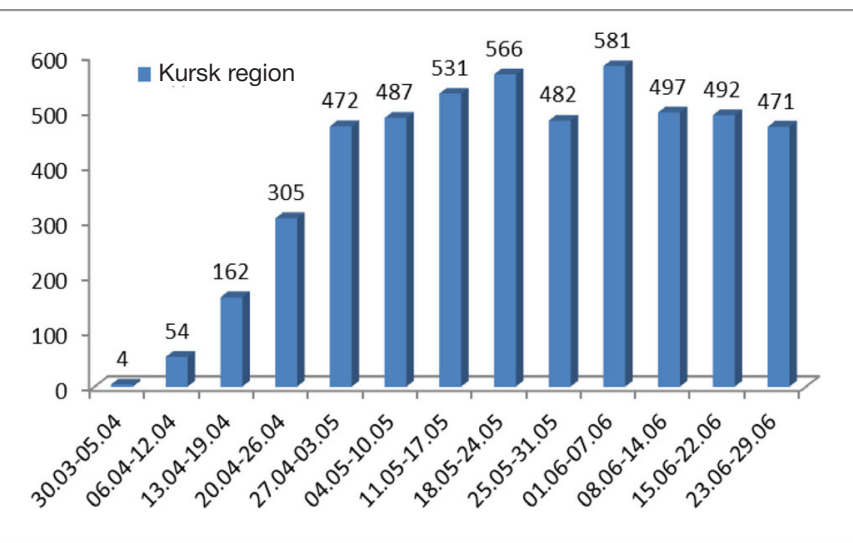

Fig. 1. Total confirmed cases of COVID-19 per week 
findings of our colleagues from Sichuan University of Science \& Engineering, the virus attacks ACE2, which is present in the vascular wall, myocardial tissue and intestinal epithelium [9]. This protein is abundant in the alveolar epithelium, that is why the virus often causes damage to the lungs. The course of the disease differs among individuals. In Voronezh region residents, the lungs are the most frequently affected organ (97\%), followed by the heart (67\%), blood vessels (54\%), the intestine (23\%), the kidneys (14\%), and the central nervous system (8\%). The diagnosis is often complicated by the lack of clear symptoms. The virus breaks the canons of classic epidemiology: the typical clinical picture of COVID-19 often contradicts the presenting complaints of a patient. In many cases, an infected individual deteriorates dramatically in no time and is at high risk of death [10].
Rapidly progressing acute respiratory distress and sepsis are not uncommon in patients with COVID-19. Many severe patients survived due to the multifaceted therapeutic approach, high-quality resuscitation and extended time spent in intensive care units. In Voronezh region, 24 hospitals were repurposed to accommodate 3,323 COVID-19 patients. This helped to prevent the catastrophic scenarios unfolding in other countries. Besides, Voronezh was one of 15 Russian cities where medical centers for infectious diseases were deployed in as little as 65 days to treat patients with COVID-19. The design was proposed by the Ministry of Defense of the Russian Federation. Such hospitals can accommodate up to 200 patients and are equipped with over 3,500 medical devices for infected patients.

Unfortunately, there is no convincing evidence proving the efficacy of medication therapy in patients with COVID-19.

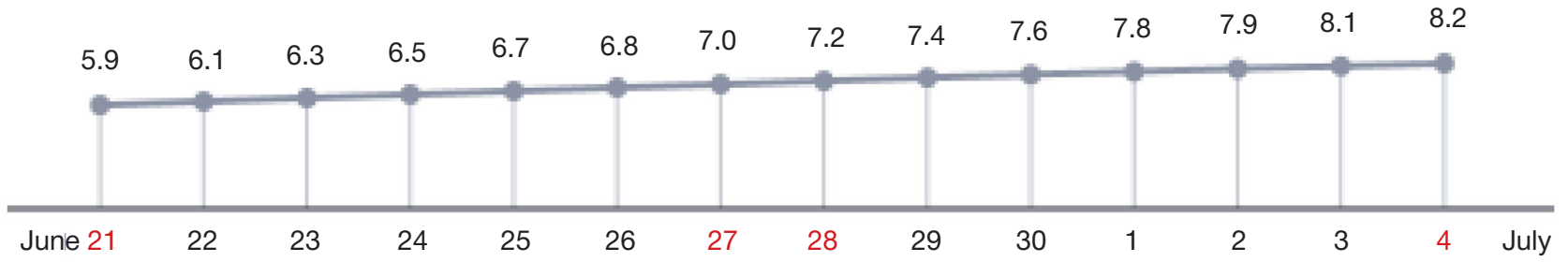

Fig. 2. Total number of COVID-19 cases in Voronezh region (according to Rospotrebnadzor and John Hopkins University)

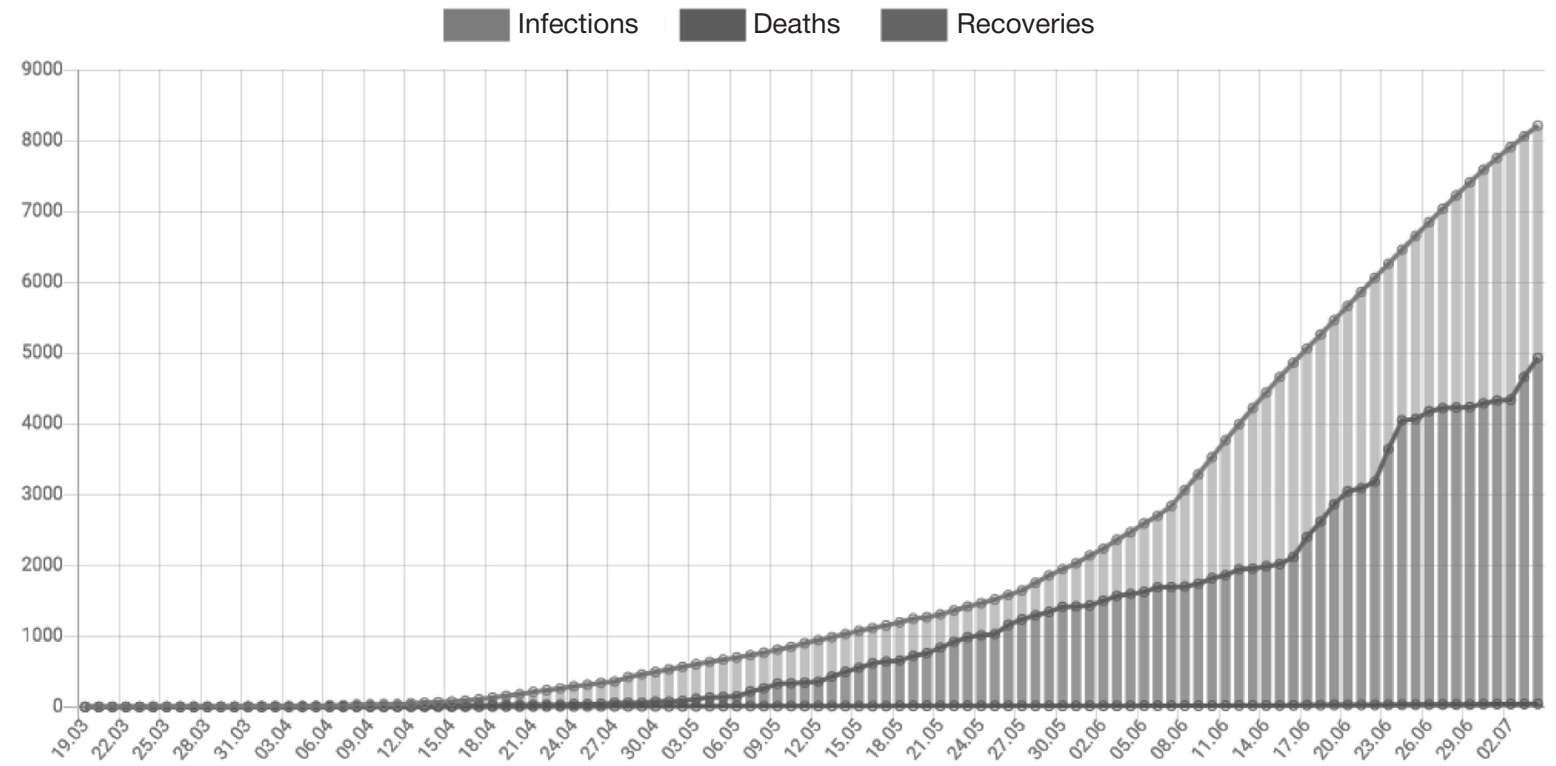

Fig. 3. cidence, recoveries and fatality rates for patients with COVID-19 (March-July 2020). Source: https://coronavirus-monitoring.info/v-voronezhskoj-oblasti/

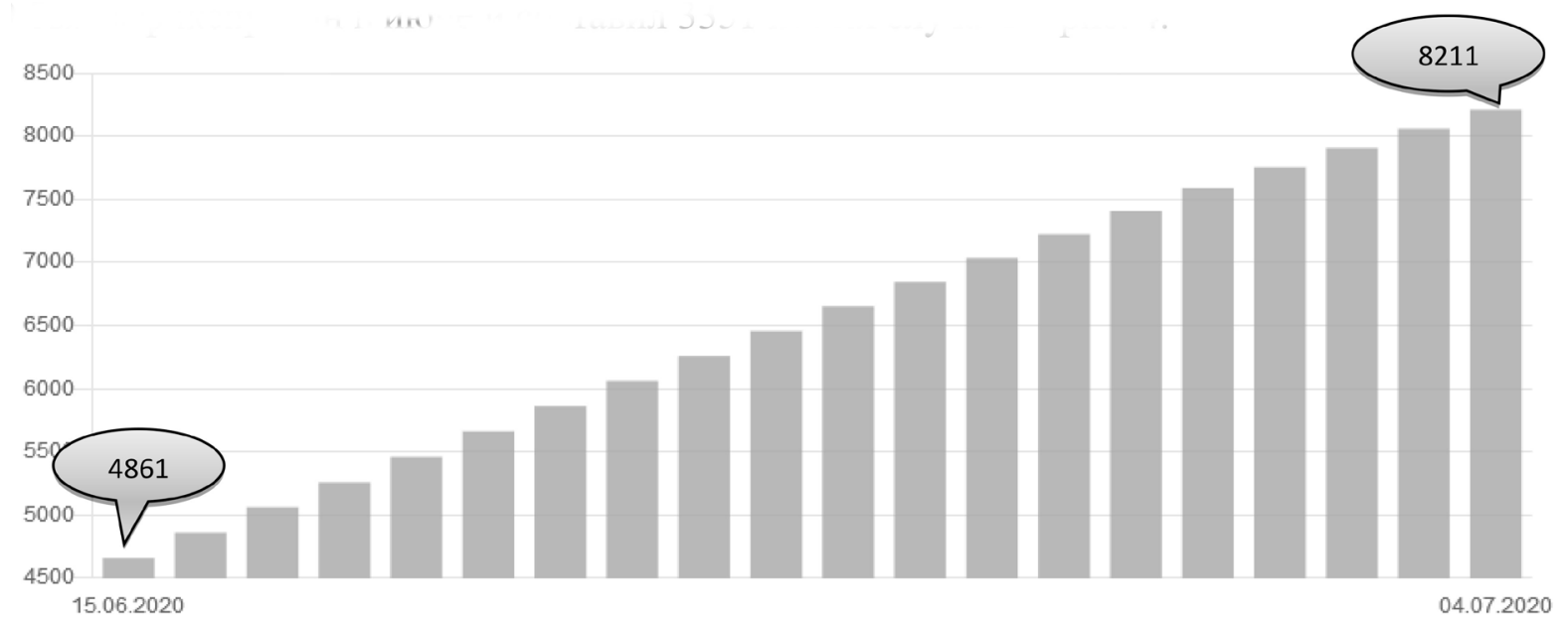

Fig. 4. Infection growth rates (March-July 2020.) Source: https://coronavirus-monitoring.info/v-voronezhskoj-oblasti/ 
According to the literature, there are a few drugs that target the underlying cause of SARS-CoV- and MERS-CoV-associated atypical pneumonia and are normally used in combination [11]. They are ribavirin, lopinavir+ritonavir and synthetic interferons. However, it is difficult to draw any firm conclusion about their efficacy based on patients' outcomes; therefore, they are used only at the approval of a medical consultative board if the potential benefit of the drug outweighs the risks. Besides, the virus destroys one of hemoglobin chains in red blood cells, i.e. it damages blood cells engaged in oxygen transport, leading to hypoxia $[12,13]$. In case when SARS-COV-2 simultaneously attacks different organs, it gets harder to find an effective cure.

Another promising approach to treating COVID-19 is oxygen infusion treatment; the supplied oxygen is then carried by the blood to all bodily tissues and organs. Great hopes are pinned on drugs used to treat malaria and BCG vaccines but their effect still needs to be thoroughly studied.

The Department of Healthcare of Voronezh region is taking steps to contain the epidemic; it is also concerned about the possible disease sequelae for convalescent individuals or how the epidemic will affect those who are not infected yet or whether there are latent carriers, etc. Two Voronezh city clinics (№ 11 and № 16) have opened new post-acute transitional care and rehabilitation units for patients with COVID-19. The units can accommodate up to 160 patients with mild disease, those who do not require intensive care or ventilators and those who were severely ill and are now improving.

For COVID-19 patients, recovery and death rates differ across regions. According to the official reports published on Стопкоронавирус.рф, the total death toll over the entire surveillance period was $0.54 \%$ (a total of 51 cases) for Voronezh region. In Kursk region, this figure was $0.7 \%$. The death toll was the lowest in Lipetsk and Tambov regions (0.4\% for both) and the highest in Oryol (1.4\%) and Belgorod (1\%) regions (Fig. 7 ).

The first post-mortem confirmed case of COVID-19 in Voronezh region was reported on April 12. The patient was a 65 -year old female residing in Voronezh region. Until June, the fatality rate did not exceed $0.35 \%$ but then spiked to $0.54 \%$ in just 15 days (Fig. 8 and 9).

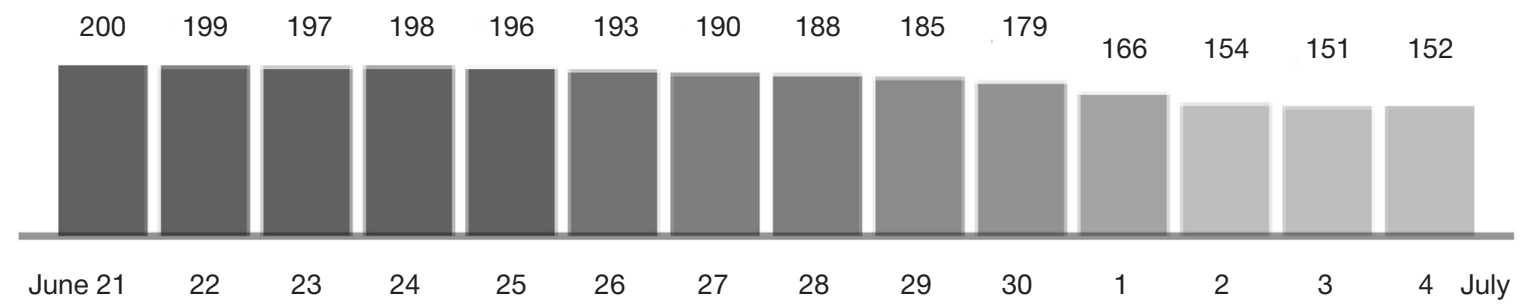

Fig. 5. New daily cases of COVID-19 (June 21-July 4, 2020)

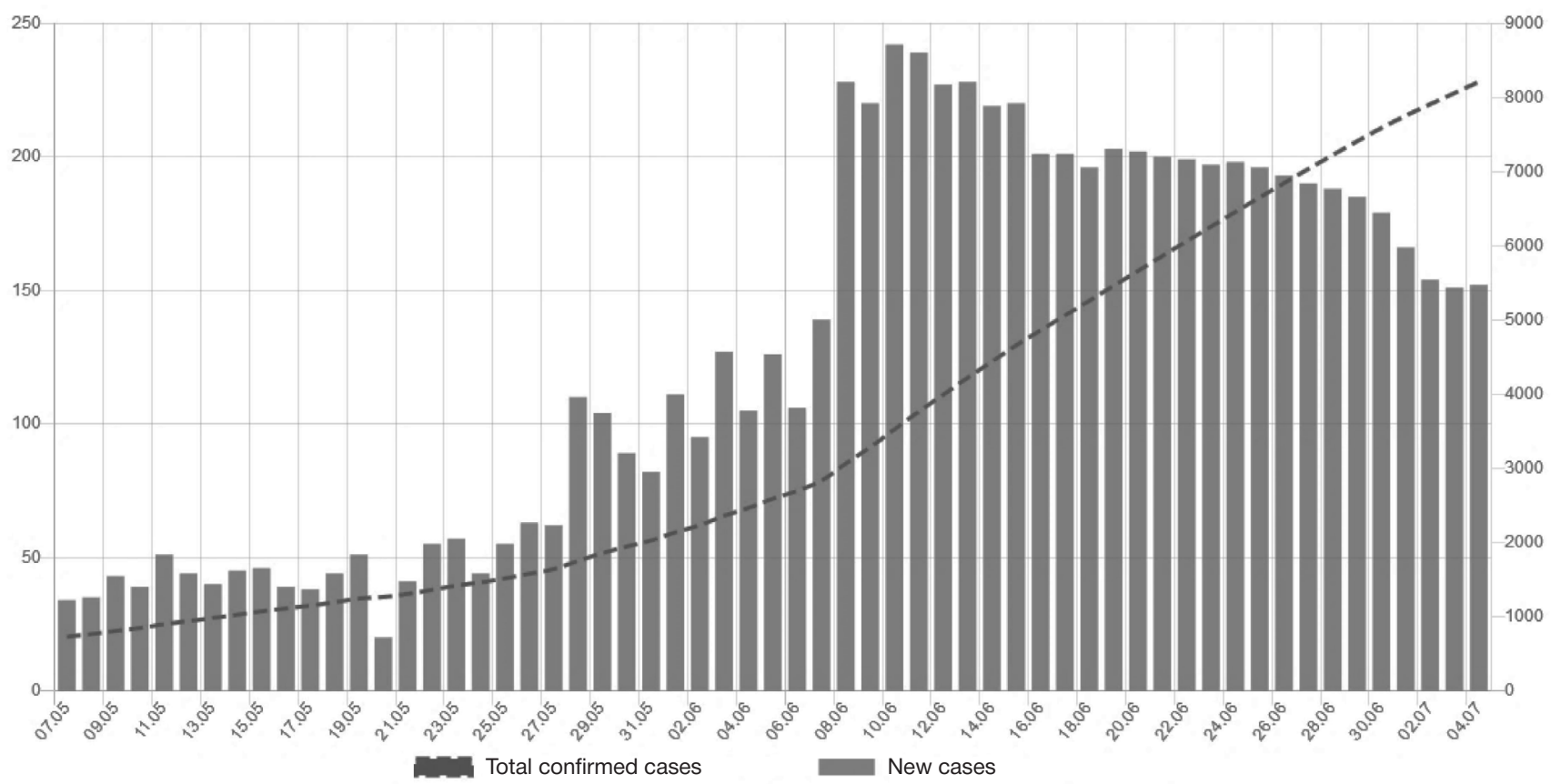

Fig. 6. Ratio of new cases to confirmed cases. Source: https://coronavirus-monitoring.info/v-voronezhskoj-oblasti/

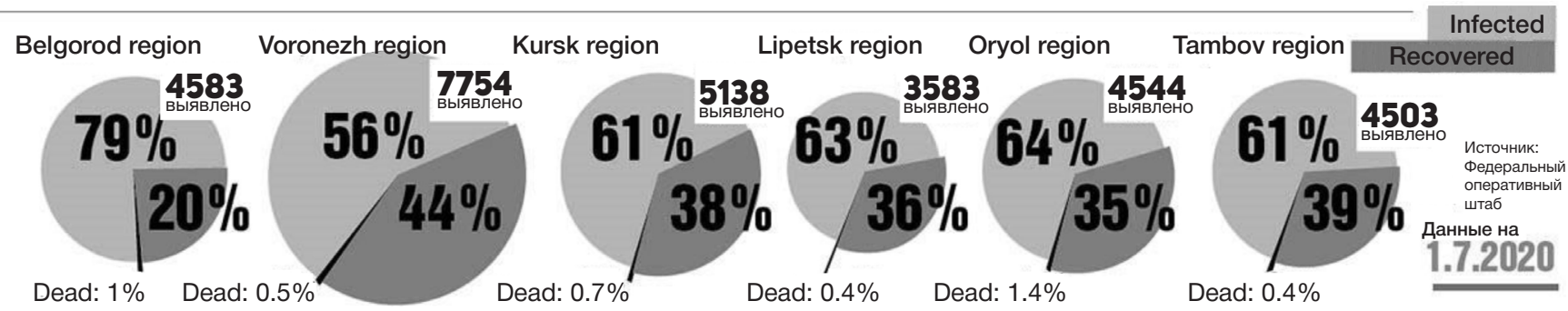

Fig. 7. Infections, recoveries and deaths in the studied bordering regions 
Normally, the fatality rate is at its highest at the beginning of an outbreak and drops to a minimum at the end of it when more mild cases are increasingly diagnosed and advanced diagnostic tests have been already introduced. At the beginning, the COVID-19 epidemic unfolded as a nosocomial outbreak. Since Russian hospitals are equipped with specific diagnostic tools, no extra time was needed for their deployment and the rising fatality rate was attributed to an increase in the number of infected individuals.

The average age of COVID-19 fatalities is 68.6 years. Statistically, individuals of advancing age are at increased risk for the infection. Co-existing chronic conditions aggravate the course of COVID-19. Importantly, the disease can be fulminating. Lethal pneumonias comprise primary viral pneumonias (days 1-7 from the onset) and secondary bacterial or viral pneumonias (weeks 2 and 3 following the onset), which is also common for other severe acute respiratory viral infections.

In light of this, measures taken by the Voronezh region administration look reasonable and far from extreme. Despite the large population size, the epidemic in Voronezh region plateaued 3.5 months after its onset, which is still not fast enough: the spread of the virus in the region was affected by a few important factors. First, from February till April there were a lot of imported coronavirus cases. Between March 24 and April 6, over 1,470 individuals came to the Central Black Earth
Belt region from 58 countries. Most of coronavirus cases in the region were imported from Thailand (265), Ukraine (179), Abkhazia (76), Turkey (57), and Armenia (51).

Another significant contributor to the spread of SarsCoV-2 infection was poor commitment to lockdown. Starting from March 20, public events were canceled and the region was on high alert. Starting from May 12, all Voronezh region residents had to wear face masks while on public transport and in shops and practice 1.5-2 m social distancing. On July 7, all restrictions were lifted, except for $65+$ year old individuals, for whom the lockdown continued.

Although the official reports provide general understanding of the situation, they still fail to answer a number of important questions. A possible correlation between the imposed containment measures and the number of COVID-19 cases is not that obvious. In Voronezh, the disease incidence peaked in mid-June after containment measures had been loosened. At the same time, according to Yandex monitoring services, adherence to lockdown restrictions was very poor in Belgorod (1.4 points on the 5-point scale), but the number of daily cases there was relatively low.

There has been a lot of change in many public sectors since the start of the epidemic in Russia, from retraining of medical personnel to timely decision making and amendments to the current legislation.

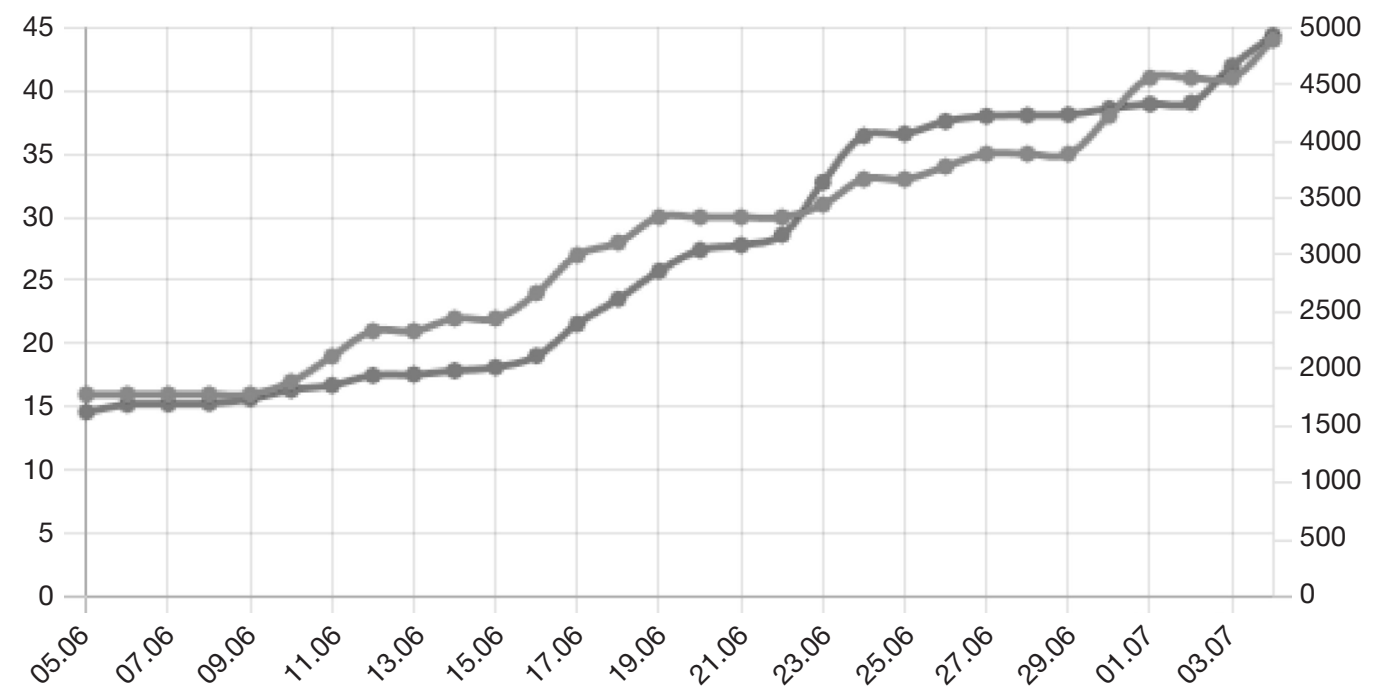

Fig. 8. Deaths and recoveries in Voronezh region

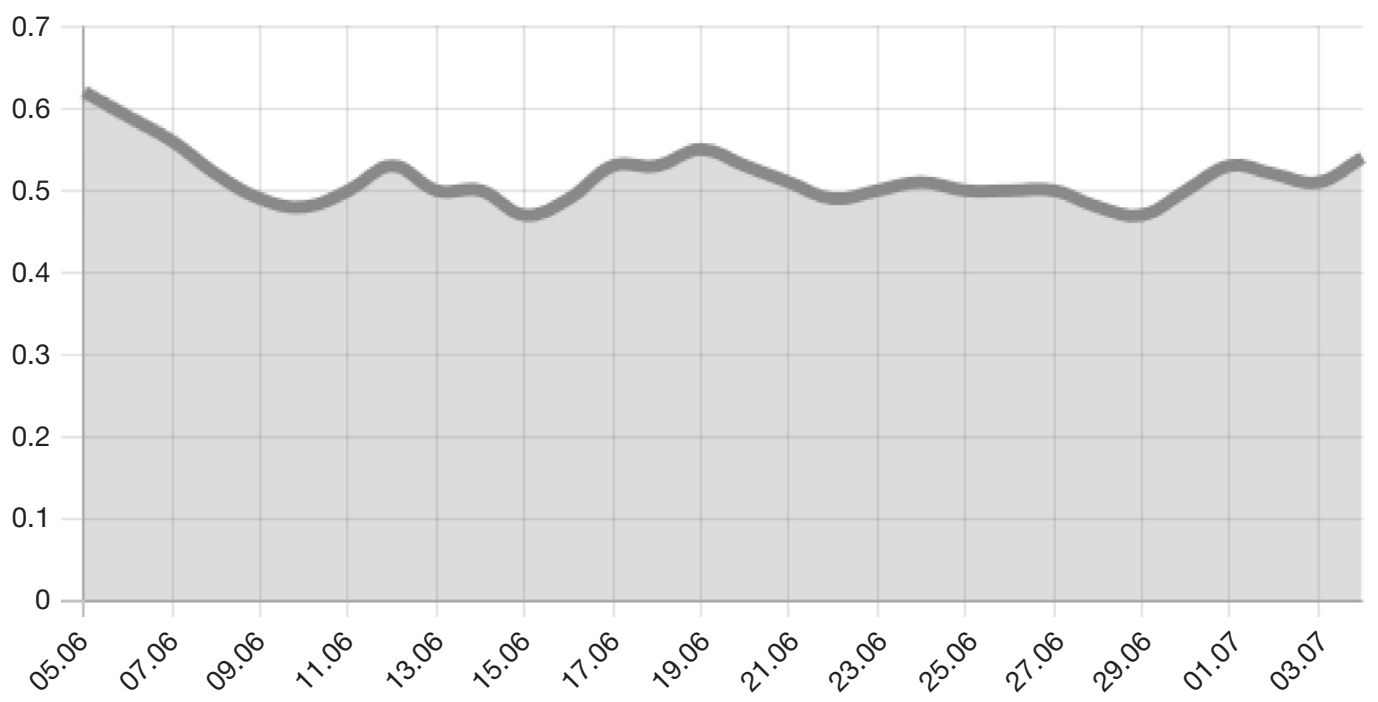

Fig. 9. Changes in the percentage of deaths from COVID-19 in Voronezh region over the 30-day period 
In Voronezh region, standard hospital wards were repurposed into COVID-19 wards; patient flow was adequately managed; a centralized remote monitoring and control system was created at the Consultative Unit for Anesthesiology and Critical Care of the Regional Center for Disaster Medicine; guidelines were elaborated to facilitate interaction between different agencies; anatomic pathology services were provided for hospitals dealing with COVID-19 patients.

Voronezh State Medical University actively took part in countering the epidemic and preventing Sars-CoV-2 spread. A resource and consultation center was opened at the Regional Department for Healthcare Development. The main goals of the Center included providing consultations to medical institutions of Voronezh, Lipetsk and Tambov regions on the diagnosis and treatment of the novel coronavirus infection and pneumonias in adult patients; analyzing the efficacy of treatment for COVID-19 patients; organizing webinars for medical personnel and educate them about the disease course, diagnostic challenges and treatment; providing consultations to pulmonologists, infectious disease specialists, anesthesiologists, and critical care specialists.

The Center worked in collaboration with the Consultative Unit for Anesthesiology and Critical Care for adult patients with COVID-19 and pneumonias created at the facilities of the remote Unit for Critical Care and Consultations and of Voronezh Region Clinical Center for Disaster Medicine and the Department of Healthcare.

Practical training for doctors, interns and other medical personnel aimed at COVID-19 prevention, diagnosis and treatment will allow the participants to improve their expertise and acquire the skills needed for future emergencies.

\section{CONCLUSION}

Resource mobilization in the wake of the Sars-CoV-2 epidemic revealed that the Russian healthcare system can successfully respond to public health emergencies. New hospitals and wards, rapid deployment of diagnostic and intensive care equipment, quick retraining of medical staff are all compelling evidence of how sufficient human and material resources can minimize the devastating effects of future epidemics, ensure quick decision making and improve the quality of medical care in "times of peace".

At the same time, the novel coronavirus pandemic unveiled the need for making amendments to the current public health legislation. This is especially true for the regulations applied to medicinal products, which do not work effectively in an emergency situation. In Russia, the law on biosecurity and biosafety is still in development. Biological threats have never been so intimidatingly real. Humankind is waging a war on pathogens at tremendous costs and with countless fatalities. The current status quo in the international relations underscores the role of fierce competition between superpowers for the right to possess cutting-edge technologies that ensure security and leadership in military, information, economic and biological sectors. But the ambitions of one state can jeopardize the security of another or even the whole group of countries, which often create political and military alliances in the face of an international or a local threat. The concept of collective security proposed by the Collective Security Treaty Organization is rooted in the idea that indivisible security is the key principle protecting interests, sovereignties and territorial integrity of member states [14, 15]. Therefore, protecting the population from the novel biological weapons of mass destruction is currently a crucial challenge for Russia.

The pandemic uncovered a number of problems facing the organization of effective public health services, especially strategic ones. It is not enough to merely state the importance of modernization - action should be taken to expedite improvement. We need a single center for decision making instead of 5 separate agencies. For example, a need arose to increase production of face masks and a range of drugs during the pandemic. Different agencies were assigned to this task, including the Ministry of Healthcare, the Ministry of Industry and Trade, Rospotrebnadzor (Russian Agency for Health and Consumer rights), Roszdravnadzor (Federal Service for Surveillance in Healthcare), and FMBA. There is a lack of cooperation between these agencies, which eventually affects the outcome.

There is a need for the overhaul of the entire strategy for the development of pharmaceutical industry in Russia. It is not enough to create an exhaustive list of drugs and their pharmaceutical ingredients that are supposed to be produced by domestic manufacturers. The pandemic revealed that many drugs used across the world are not registered in the Russian Federation. It usually takes at least half a year for a drug to be approved in Russia, which is way too long in case of an epidemic. This means that the rules regulating the use of unregistered drugs should be revised. The registration procedure should be simplified. It is reasonable to test the safety and clinical efficacy of a drug prior to the registration procedure and to conduct other phase trials afterwards. Those post-registration trials should include reporting of adverse effects; the doctors involved should be compensated for the paper work, etc. It is crucial to ramp-up production of pharmaceutical drugs for domestic use and export, conduct preclinical and clinical trials, stimulate development of effective next-generation drugs and the research potential of the Russian public health in order to be able to deal with challenges and look in the future with confidence.

Thus, there are 3 strategic priorities. The first one is reinforcing the commitment and capacities of medical institutions to effectively counter current and potential attacks. The second is creation of a self-sustainable system for providing the country and its separate regions with medical equipment and professional staff. The third priority is to provide the public health industry with cutting-edge technologies and effective drugs, along with ingredients for their production.

\section{References}

1. Lviv, D. K., shchelkanov, M. Yu., nidovirales Group / / Guide to Virology. Viruses and viral infections of humans and animals / ed. d. K. Lviv. M.: MIA, 2013. Pp. 205-208.

2. Coronavirus disease (COVID-2019) situation reports. https:// www.who.int/emergencies/diseases/novel-coronavirus-2019/ situation-reports

3. https://www.who.int/emergencies/diseases/novelcoronavirus-2019/technical-guidance/naming-the-coronavirusdisease-(covid-2019)-and-the-virus-that-causes-it

4. https://www.rosminzdrav.ru/news/2020/01/30/13236vremennye-metodicheskie-rekomendatsii-po-profilaktikediagnostike-i-lecheniyu-novoy-koronavirusnoy-infektsii-2019-ncov 
5. https://rospotrebnadzor.ru/region/rss/rss.php?ELEMENT_ID $=13524$

6. https://rospotrebnadzor.ru/deyatelnost/epidemiologicalsurveillance/?ELEMENT_ID= 13554

7. https://static-rosminzdrav.ru/system/attachments/ attaches/000/049/090/original/2019-nCoV_\%D0\%B2\%D0\%B5\%D1\% 80_3.pdf?1579987641

8. https://coronavirus-monitoring.info/v-voronezhskoj-oblasti/

9. Severe acute respiratory syndrome Coronavirus 2 isolate WuhanHu-1, complete genome. GenBank: MN908947.3. https://www. ncbi.nlm.nih.goV/nuccore/MN908947.3

10. Nikiforov V. V., Suranova T. G., Chernobrovkina T. Ya. and others. New coronavirus infection (Covid-19): clinical and epidemiological aspects//Archive of internal medicine. 2020 № 10(2). Pp. 87-93.

11. Romanov B. K. Coronavirus infection Covid-19//Safety and risk of pharmacotherapy. 2020 \# 8(1) p. 3-8.

12. Shchelkanov M. Yu., Kolobukhina L. V., Lviv D. K. human

\section{Литература}

1. Львов Д. К., Щелканов М.Ю. Отряд Nidovirales // Руководство по вирусологии. Вирусы и вирусные инсекции человека и животных / под ред. Д.К. Львова. М.: МИА, 2013. С. 205-208.

2. Coronavirus disease (COVID-2019) situation reports. https:// www.who.int/emergencies/diseases/novel-coronavirus-2019/ situation-reports

3. https://www.who.int/emergencies/diseases/novelcoronavirus-2019/technical-guidance/naming-the-coronavirusdisease-(covid-2019)-and-the-virus-that-causes-it

4. https://www.rosminzdrav.ru/news/2020/01/30/13236-vremennyemetodicheskie-rekomendatsii-po-profilaktike-diagnostike-ilecheniyu-novoy-koronavirusnoy-infektsii-2019-ncov

5. https://rospotrebnadzor.ru/region/rss/rss.php?ELEMENT_ID=13524

6. https://rospotrebnadzor.ru/deyatelnost/epidemiologicalsurveillance/?ELEMENT_ID=13554

7. https://static-rosminzdrav.ru/system/attachments/ attaches/000/049/090/original/2019-nCoV_\%D0\%B2\%D0\%B5\%D1\% 80_3.pdf?1579987641

8. https://coronavirus-monitoring.info/v-voronezhskoj-oblasti/

9. Severe acute respiratory syndrome Coronavirus 2 isolate WuhanHu-1, complete genome. GenBank: MN908947.3. https://www. ncbi.nIm.nih.goV/nuccore/MN908947.3

10. Никифоров В. В., Суранова Т. Г., Чернобровкина Т. Я. и др. Новая коронавирусная инфекция (Covid-19): клинико-
Coronaviruses (Nidovirales, Coronaviridae): increased level of epidemic danger // Treating doctor. 2013. no. 10.Pp. 49-54.

13. Shchelkanov M. Yu., Ananyev V. Yu., Kuznetsov V. V., Shumatov V. B. middle Eastern respiratory syndrome: when will the smoldering hearth flare up? // Pacific medical journal. 2015. no. 2. Pp. 94-98.

14. The Concept of collective security of the States parties to the collective security Treaty of may 15, 1992 / / CSTO. Official site. URL:https://odkb-csto.org/documents/documents/kontseptsiya_ kollektivnoy_bezopasnosti_gosudarstv_uchastnikov_dogovora_o_ kollektivnoy_bezopasnosti/

15. Onishchenko G. G., Pakskina N. D., Toporkov V. P., Toporkov A.V., shiyanova A. E., Kutyrev V. V. Scientific and methodological and regulatory aspects of the implementation of the International medical and sanitary rules of 2005 on the territory of the Russian Federation. Problems of particularly dangerous infections. 2010; 3 (105): 5-12.

эпидемиологические аспекты//Архивъ внутренней медицины. 2020 №10(2). C. 87-93.

11. Романов Б. К. Коронавирусная инфекция Covid-19// Безопасность и риск фармакотерапии. 2020 № 8(1) с. 3-8.

12. Щелканов М.Ю., Колобухина Л.В., Львов Д.К. Коронавирусы человека (Nidovirales, Coronaviridae): возросший уровень эпидемической опасности // Лечащий врач. 2013. № 10. С. 49-54.

13. Щелканов М.Ю., Ананьев В.Ю., Кузнецов В.В., Шуматов В.Б. Ближневосточный респираторный синдром: когда вспыхнет тлеющий очаг? // Тихоокеанский медицинский журнал. 2015. № 2. C. 94-98.

14. Концепция коллективной безопасности государствучастников Договора о коллективной безопасности от 15 мая 1992 года // ОДКБ. Официальный сайт. URL:https://odkbcsto.org/documents/documents/kontseptsiya_kollektivnoy_ bezopasnosti_gosudarstv_uchastnikov_dogovora_o_ kollektivnoy_bezopasnosti/

15. Онищенко Г. Г., Пакскина Н. Д., Топорков В. П., Топорков А. В., Шиянова А. Е., Кутырев В. В. Научно-методические и нормативные аспекты реализации Международных медикосанитарных правил 2005 г. на территории Российской Федерации. Проблемы особо опасных инфекций. 2010; 3 (105): 5-12. 